\title{
GMR
}

\section{Chloroplast diversity of Casearia grandiflora in the Cerrado of Piauí State}

\author{
M.F. Costa ${ }^{1}$, A.A. Pereira ${ }^{2}$, J.B. Pinheiro ${ }^{2}$, M.I. Zucchi ${ }^{3}$, A.S.F. Araújo ${ }^{4}$, \\ R.L.F. Gomes ${ }^{4}$, S.E.S. Valente ${ }^{5}$, M.E.A. Oliveira ${ }^{6}$ and A.C.A. Lopes ${ }^{4}$ \\ ${ }^{1}$ Universidade Federal do Piauí, Campus Amílcar Ferreira Sobral, \\ Floriano, PI, Brasil \\ ${ }^{2}$ Departamento de Genética, Escola Superior de Agricultura "Luiz de Queiroz", \\ Universidade de São Paulo, Piracicaba, SP, Brasil \\ ${ }^{3}$ Departamento de Recursos Genéticos, Instituto Agronômico de Campinas, \\ Campinas, SP, Brasil \\ ${ }^{4}$ Departamento de Agronomia, Universidade Federal do Piauí, Campus Ininga, \\ Teresina, PI, Brasil \\ ${ }^{5}$ Departamento de Biologia, Universidade Federal do Piauí, Campus Ininga, \\ Teresina, PI, Brasil \\ ${ }^{6}$ Instituto Federal de Educação, Ciência e Tecnologia, Teresina, PI, Brasil \\ Corresponding author: M.F. Costa \\ E-mail: marconesbiologo@hotmail.com / marconescosta@ufpi.edu.br
}

Genet. Mol. Res. 16 (1): gmr16019572

Received December 9, 2016

Accepted January 23, 2017

Published February 16, 2017

DOI http://dx.doi.org/10.4238/gmr16019572

Copyright $(92017$ The Authors. This is an open-access article distributed under the terms of the Creative Commons Attribution ShareAlike (CC BY-SA) 4.0 License.

\begin{abstract}
Casearia grandiflora (Salicaceae) is a typical Cerrado species adapted to disturbed environments, making it useful for restoration projects. Knowledge of genetic diversity is important for establishing conservation strategies for this species. This study aimed to compare chloroplast haplotype diversity and structure of $C$. grandiflora, under the assumption that protected areas hold greater genetic diversity than disturbed areas. The populations studied are from Parque Nacional de Sete Cidades Conservation Unit and from the surroundings of the city of Cocal de Telha, both located in the State of Piauí. Molecular analyses were performed with seven chloroplast
\end{abstract}


microsatellite loci. The number of private haplotypes and haplotype diversity were higher in the conservation unit, which reinforces the importance of these areas in maintaining biodiversity. Analysis of molecular variance showed that most of the genetic variation is found within populations, with a moderate divergence between them $\left(F_{\mathrm{ST}}=\right.$ $0.14)$. The Bayesian analysis and discriminant analysis of principal components suggested that populations are not structured, revealing that a set of individuals from Parque Nacional de Sete Cidades were more divergent within populations than between them. Since literature has little information on C. grandiflora, the results of this study provide important contribution to a better understanding of the specie's genetic diversity.

Key words: Chloroplast microsatellites; Genetic structure; Haplotype networks; Parque Nacional de Sete Cidades

\section{INTRODUCTION}

The Brazilian Cerrado holds forests, savannas, and grasslands, comprising 11 major phytophysiognomic types, showing a gradient from open fields to dense forest formations. These formations are controlled by climate interactions, soil type, and disturbance factors such as fires and herbivory (Tarazi et al., 2013).

Due to the abundance of species and their high degree of endemism, the Cerrado is considered a hotspot for global biodiversity conservation (Myers et al., 2000); however, it is the Brazilian most threatened biome.

The conservation is a necessary condition for maintaining biodiversity levels and is an important component for the sustainability of natural populations (Moura et al., 2012). The fragmentation of natural habitats and the spatial isolation of populations may cause changes in basic evolutionary processes, such as genetic drift, selection, and migration, resulting in changes in their genetic diversity and structure (Sebbenn et al., 2011).

Several studies evaluated the genetic structure of native plant populations in the Cerrado (Collevatti et al., 2010; Telles et al., 2010; Tarazi et al., 2010; Martins et al., 2011; Moura et al., 2011). These studies aimed at determining the distribution of diversity in populations of conservation units and inferring on historical events related to the effects of human activities on ecosystems fragmentation.

In view of this, there is need to establish methodologies for the preservation and maintenance of genetic diversity of the Cerrado populations. In this context, molecular markers are important tools used in genetic research to assess diversity in natural populations. Chloroplast microsatellites are among the molecular markers that have contributed to this issue. Chloroplast DNA (cpDNA) is a maternally inherited marker that undergoes little or no recombination, and exhibits a high level of genetic diversity and significant population structure (Petit et al., 1993 Liu et al., 2016).

Piauí is the state with the highest representation of the Cerrado in the Northeast Brazil, where the biome occupies about 12 million ha of which $70.4 \%$ are in your domain area and $29.6 \%$ in the transition area (Matos and Felfili, 2010). This state has three Cerrado conservation units: the Ecological Station Uruçuí-A, the Nascentes do Rio Parnaiba, and Parque Nacional de Sete Cidades.

Genetics and Molecular Research 16 (1): gmr16019572 
The Parque Nacional de Sete Cidades, located in the northeastern portion of Piauí state, contains a mosaic of physiognomies that occur along its 6,221 ha. It is a focal for studies, particularly the long-term ones, because it is a federal conservation unit of integral protection (Matos and Felfili, 2010). The vegetation of the park is characterized by great diversity of communities, occurring in mosaics included in areas of Cerrado and Cerrado/Caatinga ecotones (Mendes et al., 2012).

Casearia grandiflora is a relatively important Cerrado species, appearing in several different surveys (Machado and Oliveira, 2000). Its flowers are greenish white, with about 7 $\mathrm{mm}$. Its leaves contain diterpene and clerodanicosides, which can be used to treat wounds and snake bites (Xia et al., 2015). It easily grows in disturbed areas, such as roadsides. Despite having a wide distribution making it useful for restoration projects, there are no reports on the biological and genetic characteristics of this species.

This study aims to evaluate the diversity and structure of two populations of $C$. grandiflora of Piauí Cerrado with chloroplast microsatellite markers. One of the populations is located within the Parque Nacional de Sete Cidades Conservation Unit and the other in the municipality of Cocal de Telha. We tested if the individuals of the conservation unit are more genetically diverse than those in the disturbed area. Since there are no studies related to the distribution of diversity and haplotype structure of natural populations of Piauí Cerrado, this presents novel results.

\section{MATERIAL AND METHODS}

\section{Study sites}

The study was carried out in two areas of Cerrado in the State of Piauí: Cocal de Telha city $\left(04^{\circ} 33^{\prime} 32^{\prime \prime} \mathrm{S}\right.$ and $\left.41^{\circ} 58^{\prime} 20^{\prime \prime} \mathrm{W}\right)$ and Parque Nacional de Sete Cidades $\left(04^{\circ} 02^{\prime} 08^{\prime \prime} \mathrm{S}\right.$ and $41^{\circ} 40^{\prime} 45^{\prime \prime} \mathrm{W}$ ), with a distance of $67 \mathrm{~km}$ between them, both occurring within the vegetation profile of Cerrado sensu stricto. Parque Nacional de Sete Cidades is a conservation unit established in 1961, located between Brasileira and Piracuruca cities in northern Piauí State (Mendes et al., 2012). Eighty individuals were collected, including two populations.

The vegetation of Cocal de Telha region is characterized by a great variety of communities occurring in mosaics included in the Cerrado. The rainfall is defined as Equatorial Maritime regime, with annual isohyets between $800-1600 \mathrm{~mm}$, with about 5-6 months as the rainy season and the remainder of the year as the driest season. The months between February and April correspond to the wettest trimester of the region (Aguiar and Camargo, 2004).

The choice of these sites aimed at comparing the diversity in the population of the Parque Nacional de Sete Cidades Conservation Unit to the population of Cocal de Telha located around the BR-343 highway, which is under greater human disturbance.

\section{Extraction and quantification of DNA}

Samples of young leaves were collected and transported in liquid Nitrogen to the Molecular Biology Laboratory of Piauí Federal University, where they were conserved in freezers. DNA extraction was performed with the DNeasy Plant Mini kit (Qiagen Inc., Valencia, CA, USA) according to supplier's recommendations.

The quantification of the extracted DNA was performed by electrophoresis on $0.8 \%$

Genetics and Molecular Research 16 (1): gmr16019572 
agarose gels (w/v), prepared with $0.5 \mathrm{X}$ TBE buffer (Tris-borate-EDTA) and stained once with SYBR ${ }^{\circledR}$ Safe DNA Gel Stain (Invitrogen, Carlsbad, CA, USA), by comparison with $\lambda$-DNA bands diluted at a concentration of $100 \mathrm{ng} / \mu \mathrm{L}$. DNA samples were then diluted to a concentration of $5 \mathrm{ng} / \mu \mathrm{L}$ and stored at $-20^{\circ} \mathrm{C}$.

\section{Amplification and genotyping of chloroplast microsatellite loci}

For chloroplast microsatellite analyses, we employed universal primer pairs described to dicotyledonous angiosperms by Weising and Gardner (1999) and Chung and Staub (2003).

The microsatellite markers were amplified with the following program: a denaturation step at $94^{\circ} \mathrm{C}$ for $4 \mathrm{~min} ; 30$ cycles composed of a denaturation step at $94^{\circ} \mathrm{C}$ for $1 \mathrm{~min}$, an annealing step at $58^{\circ} \mathrm{C}$ for each pair of primers for $1 \mathrm{~min}$, an extension step at $72^{\circ} \mathrm{C}$ for $40 \mathrm{~s}$, and a final extension step at $72^{\circ} \mathrm{C}$ for $10 \mathrm{~min}$.

After the amplification of the chloroplast microsatellite loci, the size of the alleles was determined in the LI-COR DNA Analyzer 4300s (LI-COR Corporate) automated sequencer. The genotypes of individuals were automatically determined with the aid of 50-350-bp IRDye-700 and IRDye 800 (LI-COR Corporate) molecular size standards, with the program Saga $^{\mathrm{TM}}$ (LI-COR Corporate), and then visually inspected.

\section{Statistical analyses}

We estimated the number of haplotypes, the number of private haplotypes for each population (NPH), the proportion of private haplotypes, the haplotype diversity (h), and the effective number of haplotypes, using GenAlEx 6.5 (Peakall and Smouse, 2012). Analysis of molecular variance (AMOVA) was performed using Arlequin 3.5 (Excoffier and Lischer, 2010) in order to estimate the proportion of genetic variation between and within populations.

The admixture of individuals between populations was evaluated using the Bayesian analysis of genetic structure described by Pritchard et al. (2000) with STUCTURE 2.3.1. Ten independent simulations were carried out for each number of $K$ groups, with $K$ ranging from 1 to 10 , using the correlated allele frequencies and admixture models of ancestry, with 500,000 MCMC replicates after the burn-in period of 100,000 . The most likely number of clusters was found using Structure Harvester (Earl and vonHoldt, 2012) following the $\Delta K$ criteria (Evanno et al., 2005).

The genetic structure of populations was also evaluated with discriminant analysis of principal component (DAPC; Jombart et al., 2010), using the adegenet package for the $\mathrm{R}$ version 2.11 platform (R Core Team 2010 Development). The DAPC is based on data transformation by principal component analysis. The adegenet package proposes the $\alpha$-score calculation to assess the optimal number of principal components to be retained in the analysis. Using this procedure, only the first principal component, corresponding to $53.43 \%$ of the total variation, was retained for the analysis.

The haplotype network was built with the Median Joining method, using Network v.4.610 (Bandelt et al., 1999). This method of clustering is based on coalescence theory and has been used as an alternative to Wagner's parsimony, for providing better connections between haplotypes (Excoffier and Smouse, 1994). In this analysis, DNA haplotypes are related by mutation and arranged in a network. Network nodes represent each haplotype, while the distance between them is proportional to the number of mutations. The number of mutations

Genetics and Molecular Research 16 (1): gmr16019572 
throughout the network was used as an evolutionary divergence measure between any two haplotypes (Excoffier et al., 1992).

\section{RESULTS AND DISCUSSION}

Of the universal chloroplast microsatellite primers tested, 12 could be amplified (ccpm1， cсpm2， cсpm7， ccSSR-3， ccSSR-4， ccSSR-5， ccSSR-6， ccSSR-9， ccSSR-10, ccSSR-11, ccSSR-20, and ccSSR-22), but only 7 were polymorphic: ccSSR-3, ccSSR-4, ccSSR-6, ccSSR-9, ccSSR-10, ccSSR-11, and ccSSR-22. This set of chloroplast microsatellites obtained 10 haplotypes (Table 1).

\section{Table 1. Constitution of haplotypes.}

\begin{tabular}{l|c|c|c|c|c|c|c}
\hline Haplotypes & ccSSR-3 & ccSSR-4 & ccSSR-6 & ccSSR-9 & ccSSR-10 & ccSSR-11 & ccSSR-22 \\
\hline 1 & 191 & 178 & 191 & 200 & 130 & 122 & 114 \\
\hline 2 & 191 & 178 & 197 & 200 & 130 & 122 & 108 \\
\hline 3 & 191 & 178 & 197 & 200 & 130 & 124 & 114 \\
\hline 4 & 191 & 183 & 197 & 196 & 135 & 122 & 114 \\
\hline 5 & 191 & 183 & 197 & 200 & 130 & 122 & 108 \\
\hline 6 & 191 & 183 & 197 & 200 & 135 & 122 & 114 \\
\hline 7 & 191 & 183 & 191 & 200 & 130 & 122 & 114 \\
\hline 8 & 191 & 183 & 197 & 200 & 130 & 122 & 114 \\
\hline 9 & 191 & 183 & 197 & 200 & 130 & 124 & 114 \\
\hline 10 & 193 & 183 & 197 & 200 & 130 & 124 & 114 \\
\hline
\end{tabular}

The locus ccSSR-10 had the highest number of alleles for the population of Parque Nacional de Sete Cidades, suggesting that this locus underwent a larger number of mutations. On the other hand, most of the loci were monomorphic for the population of Cocal de Telha, where only the ccSSR-3 was polymorphic.

The population of Parque Nacional de Sete Cidades had higher number of haplotypes $(\mathrm{H}=9)$ and higher haplotype diversity $(\mathrm{h}=0.674)$ than the population of Cocal de Telha $(\mathrm{H}=2 ; \mathrm{h}=0.139)$. The number of private haplotypes was also higher for Parque Nacional de Sete Cidades $(\mathrm{NPH}=8)$ than in individuals from Cocal de Telha $(\mathrm{NPH}=1)$. The estimates of haplotype diversity reveal that the population in the conservation unit had greater genetic diversity and confirms the effectiveness of protected areas for the preservation and maintenance of genetic diversity of natural species.

Based on the data of haplotype frequencies (Table 2), haplotype 9 is the most common in both populations with frequency of $40 \%$ for the population of Parque Nacional de Sete Cidades, and $92.5 \%$ for Cocal de Telha.

Table 2. Haplotype frequency in populations of Casearia grandiflora.

\begin{tabular}{l|c|c}
\hline cpDNA haplotypes & Parque Nacional de Sete Cidades & Cocal de Telha \\
\hline 1 & 00.025 & 0.00 \\
\hline 2 & 00.025 & 0.00 \\
\hline 3 & 00.025 & 0.00 \\
\hline 4 & 00.025 & 0.00 \\
\hline 5 & 00.025 & 0.00 \\
\hline 6 & 00.025 & 0.00 \\
\hline 7 & 0.050 & 0.00 \\
\hline 8 & 0.400 & 0.00 \\
\hline 9 & 0.400 & 0.925 \\
\hline 10 & 0.00 & 0.075 \\
\hline
\end{tabular}

Genetics and Molecular Research 16 (1): gmr16019572 
The haplotype network (Figure 1) reveals that haplotype 9 is shared between the two populations and it is possibly the ancestral haplotype according to the theory of coalescence (Posada and Crandall, 2001), where the most frequent haplotypes are probably the oldest ones. The haplotype 9 differs from haplotypes 10,3 , and 8 by a single mutation, as well as haplotype 8 differs from haplotypes 5,6 , and 7 also for one mutation, while haplotype 5 differs from haplotype 2 by two mutational steps.

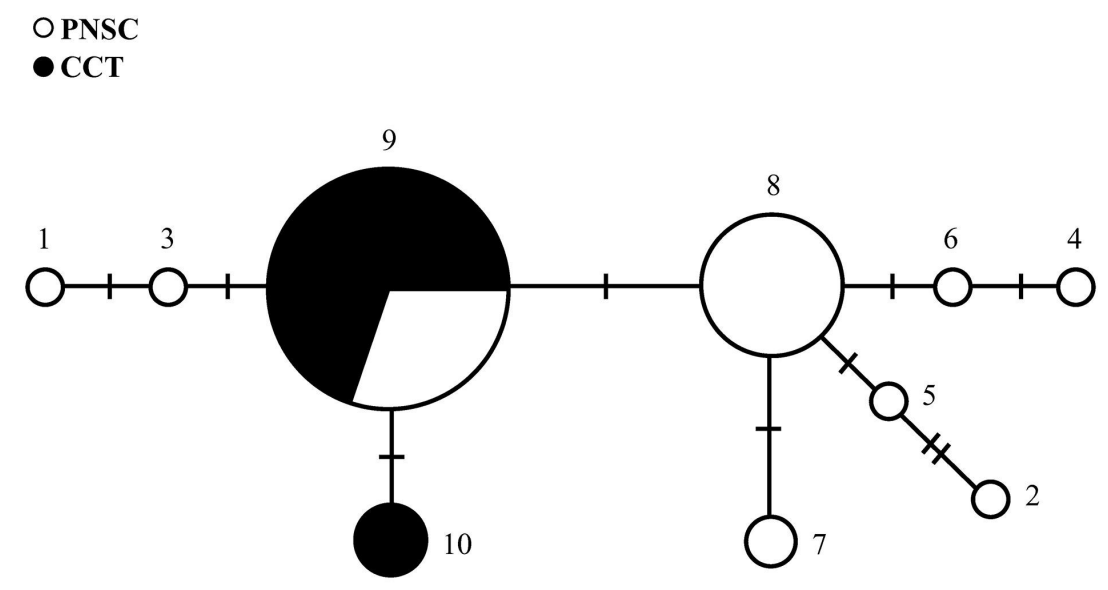

Figure 1. Haplotype network, the size of each circle is proportional to the overall frequency of each haplotype. The colors of the circles indicate the occurrence of these haplotypes in the two population groups. Each line represents one mutational step. PNSC $=$ Parque Nacional de Sete Cidades and CCT $=$ Cocal de Telha

Bayesian clustering analysis did not detected the formation of clusters, and any of the individuals had similar probabilities of belonging to either one of the populations. This suggests that the populations are not genetically differentiated.

Discriminant analysis of principal components is an excellent tool for exploring the genetic structure of populations without strong genetic assumptions of Bayesian clustering, such as adherence to Hady-Weinberg equilibrium and linkage equilibrium between loci (Jombart et al., 2009). Thus, this analysis provides an alternative to Bayesian clustering algorithms, such as the implemented in STRUCTURE (Pritchard et al., 2000). The analysis evidenced low haplotype differentiation between the populations of Parque Nacional de Sete Cidades and Cocal de Telha, confirming the absence of genetic structure.

The reproductive biology of $C$. grandiflora may be an important factor to explain the observed genetic uniformity. According to Moura et al. (2012) in natural populations, one of the main factors that influence the genetic structure of populations is the mating system, which determines the extent of gene flow between populations. Outcrossing plants, unlike autogamous ones, tend to have high levels of genetic variability within populations and low genetic differentiation between populations (Zanella et al., 2012).

Although the populations are not genetically structured, it can be seen that some individuals of Parque Nacional de Sete Cidades are more divergent from the population of Cocal de Telhas, which shows a more restricted distribution (Figure 2). This result may be due to greater anthropic disturbance in the population of Cocal de Telha, which may compromise the maintenance of genetic variability due to habitat fragmentation, for example.

Genetics and Molecular Research 16 (1): gmr16019572 


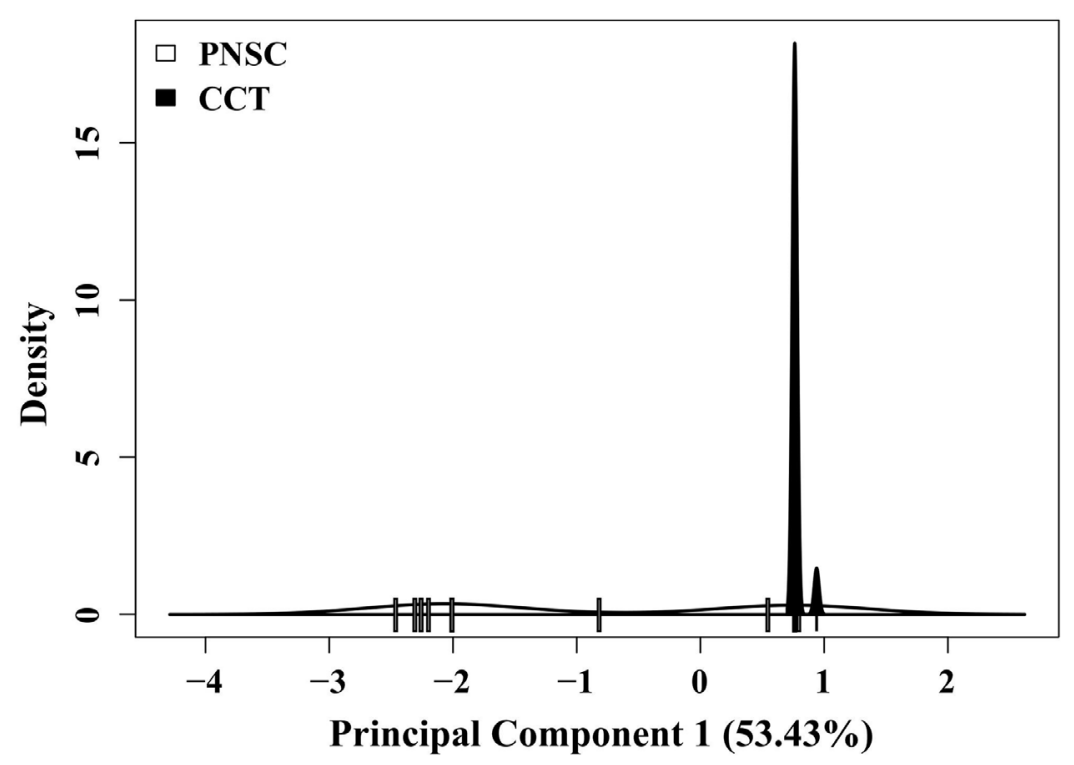

Figure 2. Discriminant principal components analysis. $\mathrm{PNSC}=$ Parque Nacional de Sete Cidades and CCT $=$ Cocal de Telha.

The destruction of natural habitats for the human occupation causes ecosystem fragmentation, leading to a loss of biodiversity, which can impose evolutionary constraints on the species. These, in turn often have negative effects on the biota and can lead to increased frequency of deleterious alleles compromising the persistence and adaptation of species to the environment (Habel and Zachas, 2012).

AMOVA derived from a matrix of squared distances between pairs of haplotypes produces estimates of variance components, reflecting the haplotype diversity in different levels of hierarchical subdivision. The results of AMOVA showed that most of the genetic variation was found within populations $(85 \%)$.

The observed value of $F_{\mathrm{ST}}(0.14)$ suggests moderate genetic structure among populations (Wright, 1978). The analysis of haplotype frequency revealed that, although both populations share the haplotype 9, the population of Parque Nacional de Sete Cidades had eight haplotypes that were not found in Cocal de Telha, which may explain the moderate level of population structure.

Based on the results of Bayesian and multivariate analyses, it can be initially rejected the hypothesis of strong population structure. It is possible that pollen flow between populations still exists, despite the fact that the populations are $67 \mathrm{~km}$ apart. It is also possible that there is restriction to pollen flow, but it may not be older enough leading to genetic structure between populations. However, forest fragmentation and anthropic disturbances may lead to increasing $F_{\text {ST }}$ estimates over time.

According to Haddad et al. (2015), fragmentation of habitats has a long term effect on biodiversity, and for decades there was a reduction of about $50 \%$ of some species diversity distributed across the five continents. In addition, about $70 \%$ of forests in the world are threatened by human activities. 
From the molecular analysis it was possible to estimate the haplotype diversity, which suggested that there are differences in the genetic diversity of $C$. grandiflora population of the Parque Nacional de Sete Cidades Conservation Unit and under human intervention area of the population of the municipality of Cocal de Telha. These results show that populations in less urbanized areas have greater genetic diversity and confirm the effectiveness of protected areas for the conservation of genetic diversity of the species. The results obtained for $C$. grandiflora will certainly bring benefits to the conservation of other native species that occur in this area the Cerrado of Piauí.

\section{ACKNOWLEDGMENTS}

The authors thank FAPEPI (Fundação de Amparo à Pesquisa do Estado do Piauí) for financial support through the PRONEX (FAPEPI/CNPq).

\section{REFERENCES}

Aguiar LMS and Camargo AJA (2004). Cerrado: ecologia e caracterização. Planaltina: Embrapa Cerrados, Brasília, 249. Bandelt HJ, Forster P and Röhl A (1999). Median-joining networks for inferring intraspecific phylogenies. Mol. Biol. Evol. 16: 37-48. http://dx.doi.org/10.1093/oxfordjournals.molbev.a026036

Chung SM and Staub JE (2003). The development and evaluation of consensus chloroplast primer pairs that possess highly variable sequence regions in a diverse array of plant taxa. Theor. Appl. Genet. 107: 757-767. http://dx.doi. org/10.1007/s00122-003-1311-3

Collevatti RG, Estolano R, Garcia SF and Hay JD (2010). Short-distance pollen dispersal and high self-pollination in a bat-pollinated Neotropical tree. Tree Genet. Genomes 6: 555-564 http://dx.doi.org/10.1007/s11295-010-0271-4.

Earl DA and vonHoldt BM (2012). STRUCTURE HARVESTER: a website and program for visualizing STRUCTURE output and implementing the Evanno method. Conserv. Genet. 4: 359-361 http://dx.doi.org/10.1007/s12686-011-9548-7.

Evanno G, Regnaut S and Goudet J (2005). Detecting the number of clusters of individuals using the software STRUCTURE: a simulation study. Mol. Ecol. 14: 2611-2620. http://dx.doi.org/10.1111/j.1365-294X.2005.02553.x

Excoffier L and Smouse PE (1994). Using allele frequencies and geographic subdivision to reconstruct gene trees within a species: molecular variance parsimony. Genetics 136: 343-359.

Excoffier L and Lischer HEL (2010). Arlequin suite ver 3.5: a new series of programs to perform population genetics analyses under Linux and Windows. Mol. Ecol. Resour. 10: 564-567. http://dx.doi.org/10.1111/j.1755-0998.2010.02847.x

Excoffier L, Smouse PE and Quattro JM (1992). Analysis of molecular variance inferred from metric distances among DNA haplotypes: application to human mitochondrial DNA restriction data. Genetics 131: 479-491.

Habel JC and Zachas FE (2012). Habitat fragmentation versus fragmented habitats. Biodivers. Conserv. 21: 2987-2990 http://dx.doi.org/10.1007/s10531-012-0349-4.

Haddad NM, Brudvig LA, Clobert J, Davies KF, et al. (2015). Habitat fragmentation and its lasting impact on Earth's ecosystems. Sci. Adv. 1: e1500052 http://dx.doi.org/10.1126/sciadv.1500052.

Jombart T, Pontier D and Dufour AB (2009). Genetic markers in the playground of multivariate analysis. Heredity 102: 330-341. http://dx.doi.org/10.1038/hdy.2008.130

Jombart T, Devillard S and Balloux F (2010). Discriminant analysis of principal components: a new method for the analysis of genetically structured populations. BMC Genet. 11: 94 http://dx.doi.org/10.1186/1471-2156-11-94.

Liu HL, Zhang RQ, Geng ML, Zhu JY, et al. (2016). Chloroplast analysis of Zelkova schneideriana (Ulmaceae): genetic diversity, population structure, and conservation implications. Genet. Mol. Res. 15: 1-9 $\underline{\mathrm{http} / / / \mathrm{dx} . d o i . o r g / 10.4238 / \mathrm{gmr} .15017739 .}$

Machado AO and Oliveira PEAM (2000). Biologia floral e reprodutiva de Casearia grandiflora Camb. (Flacourtiaceae). Rev. Bras. Bot. Braz. J. Bot. 23: 283-290. http://dx.doi.org/10.1590/S0100-84042000000300004

Martins K, Chaves LJ, Vencovsky R, Kageyama PY, et al. (2011). Genetic structure based on nuclear and chloroplast microsatellite loci of Solanum lycocarpum A. St.-Hil. (Solanaceae) in Central Brazil. Genet. Mol. Res. 10: 665677. http://dx.doi.org/10.4238/vol102gmr1046

Matos MQ and Felfili JM (2010). Florística, fitossociologia e diversidade da vegetação arbórea nas matas de galeria do Parque Nacional de Sete Cidades (PNSC), Piauí, Brasil. Acta Bot. Bras. 24: 483-496. http://dx.doi.org/10.1590/ $\underline{\text { S0102-33062010000200019 }}$

Genetics and Molecular Research 16 (1): gmr16019572 
Mendes MRA, Munhoz CBR, Silva JMC and Castro AAJF (2012). Relação entre a vegetação e as propriedades do solo em áreas de campo limpo úmido no Parque Nacional de Sete Cidades, Piauí, Brasil. Rodriguésia 63: 971-984. http:// dx.doi.org/10.1590/S2175-78602012000400014

Moura TM, Sebbenn AM, Martins K, Moreno MA, et al. (2011). Allelic diversity in populations of Solanum lycocarpum A. St.-Hil (Solanaceae) in a protected area and a disturbed environment. Acta Bot. Bras. 25: 937-940. http://dx.doi. org/10.1590/S0102-33062011000400023

Moura TM, Martins K, Sujii PS, Sebbenn AM, et al. (2012). Genetic structure in fragmented populations of Solanum lycocarpum A. St.-Hil. with distinct anthropogenic histories in a Cerrado region of Brazil. Genet. Mol. Res. 11: 26742682 http://dx.doi.org/10.4238/2012.July.10.16.

Myers N, Mittermeier RA, Mittermeier CG, da Fonseca GA, et al. (2000). Biodiversity hotspots for conservation priorities. Nature 403: 853-858. http://dx.doi.org/10.1038/35002501

Peakall R and Smouse PE (2012). GenAlEx 6.5: genetic analysis in Excel. Population genetic software for teaching and research - an update. Bioinformatics 28: 2537-2539. http://dx.doi.org/10.1093/bioinformatics/bts460

Petit RJ, Kremer A and Wagner DB (1993). Geographic structure of chloroplast DNA polymorphisms in European oaks. Theor. Appl. Genet. 87: 122-128 http://dx.doi.org/10.1007/BF00223755.

Posada D and Crandall KA (2001). Intraspecific gene genealogies: trees grafting into networks. Trends Ecol. Evol. 16: 37-45. http://dx.doi.org/10.1016/S0169-5347(00)02026-7

Pritchard JK, Stephens M and Donnelly P (2000). Inference of population structure using multilocus genotype data. Genetics 155: 945-959.

Sebbenn AM, Carvalho ACM, Freitas MLM, Moraes SMB, et al. (2011). Low levels of realized seed and pollen gene flow and strong spatial genetic structure in a small, isolated and fragmented population of the tropical tree Copaifera langsdorffii Desf. Heredity 106: 134-145. http://dx.doi.org/10.1038/hdy.2010.33

Soares TN, Chaves LJ, de Campos Telles MP, Diniz-Filho JAF, et al. (2008). Landscape conservation genetics of Dipteryx alata ("baru" tree: Fabaceae) from Cerrado region of central Brazil. Genetica 132: 9-19 http://dx.doi.org/10.1007/ s10709-007-9144-7.

Tarazi R, Moreno MA, Gandara FB, Ferraz EM, et al. (2010). High levels of genetic differentiation and selfing in the Brazilian cerrado fruit tree Dipteryx alata Vog. (Fabaceae). Genet. Mol. Biol. 33: 78-85. http://dx.doi.org/10.1590/ $\underline{\mathrm{S} 1415-47572010005000007}$

Tarazi R, Sebbenn AM, Kageyama PY and Vencovsky R (2013). Long-distance dispersal in a fire- and livestock-protected savanna. Ecol. Evol. 3: 1003-1015 http://dx.doi.org/10.1002/ece3.515.

Telles MPC, Silva SP, Ramos JR, Soares TN, et al. (2010). Estrutura genética em populações naturais de Tibouchina papyrus em áreas de campo rupestre no cerrado. Rev. Bras. Bot. Braz. J. Bot. 33: 291-300. http://dx.doi.org/10.1590/ $\underline{\text { S0100-84042010000200010 }}$

Weising K and Gardner RC (1999). A set of conserved PCR primers for the analysis of simple sequence repeat polymorphisms in chloroplast genomes of dicotyledonous angiosperms. Genome 42: 9-19. http://dx.doi.org/10.1139/ g98-104

Wright S (1978). Evolution and the Genetics of Populations. Variability Within and Among Natural Populations. University of Chicago Press, Chicago. 590.

Xia L, Guo Q, Tu P and Chai X (2015). The genus Casearia: a phytochemical and pharmacological overview. Phytochem. Rev. 14: 99-135 http://dx.doi.org/10.1007/s11101-014-9336-6.

Zanella CM, Janke A, Palma-Silva C, Kaltchuk-Santos E, et al. (2012). Genetics, evolution and conservation of Bromeliaceae. Genet. Mol. Biol. 35 (4 Suppl): 1020-1026. http://dx.doi.org/10.1590/S1415-47572012000600017

Genetics and Molecular Research 16 (1): gmr16019572 